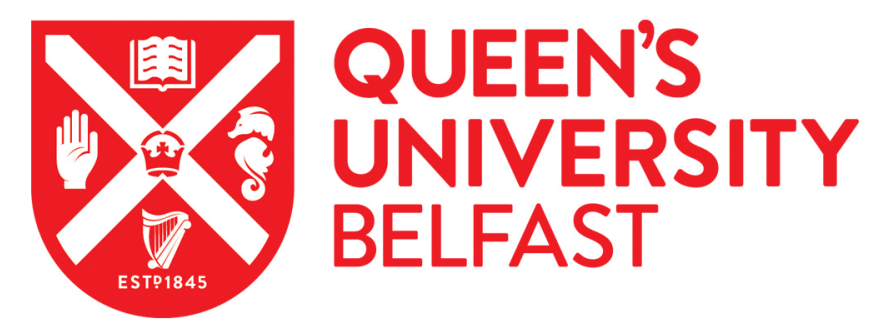

\title{
Spectrokinetic investigation of reverse water-gas-shift reaction intermediates over a Pt/CeO2 catalyst
}

Goguet, A., Tibiletti, D., Meunier, F., Breen, J., \& Burch, R. (2004). Spectrokinetic investigation of reverse watergas-shift reaction intermediates over a Pt/CeO2 catalyst. Journal of Physical Chemistry B, 108(52)(52), 2024020246. https://doi.org/10.1021/jp047242w

Published in:

Journal of Physical Chemistry B

Queen's University Belfast - Research Portal:

Link to publication record in Queen's University Belfast Research Portal

\section{General rights}

Copyright for the publications made accessible via the Queen's University Belfast Research Portal is retained by the author(s) and / or other copyright owners and it is a condition of accessing these publications that users recognise and abide by the legal requirements associated with these rights.

Take down policy

The Research Portal is Queen's institutional repository that provides access to Queen's research output. Every effort has been made to ensure that content in the Research Portal does not infringe any person's rights, or applicable UK laws. If you discover content in the Research Portal that you believe breaches copyright or violates any law, please contact openaccess@qub.ac.uk. 


\title{
Spectrokinetic Investigation of Reverse Water-Gas-Shift Reaction Intermediates over a $\mathrm{Pt} / \mathrm{CeO}_{2}$ Catalyst
}

\author{
Alexandre Goguet, Frederic C. Meunier,* Daniele Tibiletti, John P. Breen, and Robbie Burch \\ CenTACat, School of Chemistry, Queen's University Belfast, Belfast, BT9 5AG, Northern Ireland \\ Received: June 24, 2004; In Final Form: September 6, 2004
}

\begin{abstract}
The reactivity of the surface species present over a $2 \% \mathrm{Pt} / \mathrm{CeO}_{2}$ catalyst during the reverse water-gas-shift (RWGS) reaction was investigated by a detailed operando spectrokinetic analysis. A single reactor common for the kinetic and the spectroscopic measurements was used. The reactor employed was a modified hightemperature diffuse reflectance FT-IR (DRIFT) cell from SpectraTech. The reactivity of the surface species was monitored by DRIFT spectroscopy (DRIFTS) and mass spectrometry (MS) using steady-state isotopic transient kinetic analysis (SSITKA) techniques, i.e., switching between $1 \% \mathrm{CO}_{2}+4 \% \mathrm{H}_{2}$ reaction mixtures containing either ${ }^{13} \mathrm{CO}_{2}$ or ${ }^{12} \mathrm{CO}_{2}$. The combination of these techniques allowed time-resolved simultaneous monitoring of the variation of the coverage of ${ }^{12} \mathrm{C}$ and ${ }^{13} \mathrm{C}$-containing surface intermediates and the concentration of the gas-phase products ${ }^{12} \mathrm{CO}(\mathrm{g})$ and ${ }^{13} \mathrm{CO}(\mathrm{g})$ due to the isotope exchange. These results clearly indicated that surface formates observed by DRIFTS were not the main reaction intermediates for the formation of $\mathrm{CO}(\mathrm{g})$ over the present catalyst under these experimental conditions, although the formation of $\mathrm{CO}(\mathrm{g})$ from formates was likely to occur to a limited extent. A quantitative analysis of the number of reactive surface species also showed that Pt-bound carbonyls could not be the only reaction intermediate. Surface carbonates are shown as being a main surface intermediate in the formation of $\mathrm{CO}(\mathrm{g})$. A reaction scheme involving a direct reoxidation of the ceria support by the $\mathrm{CO}_{2}$ via surface carbonates is suggested. A parallel between these results and mechanisms previously proposed for $\mathrm{CO}_{2}$ hydrogenation and $\mathrm{CO}_{2}$-reforming (i.e., dryreforming) of methane on redox oxide-supported noble metal is made. In a more general perspective, the present data underlines the feasibility and appropriateness of the DRIFT-MS-SSITKA technique based on a single reactor in providing critical information about the nature of surface species (e.g., kinetic intermediate as opposed to spectator) on catalysts when the surface species are observable by DRIFT spectroscopy.
\end{abstract}

\section{Introduction}

Infrared (IR) spectroscopy is often used to study adsorbed species and reaction intermediates over heterogeneous catalysts, but frequently this is done either under non-steady-state conditions or over time scales that are not appropriate to the ratedetermining-step. In operando steady-state kinetic methods provide a useful technique for the investigation of catalytic mechanisms on catalysts under reaction conditions. ${ }^{1}$ The collection of both infrared spectroscopic data and reaction rates (typically using mass spectrometry, noted MS) under steadystate isotopic transient kinetic analysis $\left(\right.$ SSITKA $^{2,3}$ ) conditions can allow us to directly relate the formation of a given reaction product to a particular surface intermediate. This technique has only been performed by a limited number of research groups over the past fifteen years or so. Some of the reactions that have been studied both by IR and MS under SSITKA conditions include the conversion of syngas $\left(\mathrm{CO} / \mathrm{H}_{2}\right.$ mixtures $),{ }^{4-8} \mathrm{CO}_{2^{-}}$ reforming of methane 9,10 and nitrogen oxides decomposition. ${ }^{11,12}$

To our knowledge, most of (if not all) the studies published so far on IR and MS under SSITKA conditions were based on the use of two different reactors, one for the spectroscopic measurement and another one for the kinetic analysis. While

* To whom correspondence should be addressed. E-mail: f.meunier@ qub.ac.uk. the practicability of such procedures is obvious, the utilization of a single reactor for the simultaneous monitoring of the surface species concentrations and the rates of product formation would represent a significant improvement in terms of the uniformity of the experimental parameters.

The simultaneous combination of IR + MS analyses under SSITKA conditions using a single reactor is demonstrated as a powerful and straightforward means to provide information on catalytic mechanisms in the present report. The value of this approach is exemplified by an important reaction that is relevant to the production of pure hydrogen for fuel cell applications, i.e., the reverse water-gas-shift reactions (RWGS), over a platinum-ceria catalyst, for which a number of surface intermediate species are observed under reaction conditions.

The ability of ceria to promote the water-gas-shift (WGS) reaction has attracted much attention and the activity of $\mathrm{Pt} / \mathrm{CeO}_{2}$ has been shown to exceed that of conventional $\mathrm{Cu} / \mathrm{ZnO}$ shift catalysts in some circumstances. ${ }^{13-26}$ However, it appears that the activity and stability of ceria-based formulations depends markedly on the preparation methods. ${ }^{20,27,28}$ Therefore, there is a need to better understand the way ceria-based materials operate (i.e., in terms of reaction mechanism) to allow further improvements in the formulation and preparation of catalysts.

Two main reaction mechanisms have been proposed for the WGS reaction over ceria-based materials. Gorte and coworkers. $^{20,22} 27-29$ and Flytzani-Stephanopoulos and co-workers ${ }^{29}$ proposed a redox mechanism

\subsection{1/jp047242w CCC: $\$ 27.50$ (C) 2004 American Chemical Society}

Published on Web 11/25/2004 


$$
\begin{aligned}
\mathrm{CO}(\mathrm{g})+\sigma & \rightarrow \mathrm{CO}(\text { ads }) \\
\mathrm{CO}(\text { ads })+2 \mathrm{CeO}_{2} & \rightarrow \mathrm{CO}_{2}+\mathrm{Ce}_{2} \mathrm{O}_{3}+\sigma \\
\mathrm{H}_{2} \mathrm{O}+\mathrm{Ce}_{2} \mathrm{O}_{3} & \rightarrow 2 \mathrm{CeO}_{2}+\mathrm{H}_{2}
\end{aligned}
$$

In this mechanism, $\mathrm{CO}(\mathrm{g})$ adsorbs on reduced metal sites $(\sigma)$ to form a Pt-bound carbonyl species, which then reacts with an oxygen atom coming from the ceria to form $\mathrm{CO}_{2}$. The reduced ceria is subsequently reoxidized by water, and hydrogen is produced as a result.

The second main reaction mechanism was proposed by Shido and Iwasawa ${ }^{15}$ and Jacobs et al., ${ }^{30,31}$ and is partly based on transient IR data and TPD studies. The decomposition of the surface species formed under reaction conditions (e.g., formates, carbonyls, and carbonates) in an inert purge gas or atypical feed was studied and it was concluded that the main reaction intermediate was a bidentate formate produced by reaction of $\mathrm{CO}$ with terminal hydroxyl groups on ceria. In this nonredox mechanism, the rate-determining step is the decomposition of this formate into $\mathrm{H}_{2}$ and a monodentate carbonate.

The role of the carbonate species observed over WGS catalysts is intriguing. Hilaire et al. ${ }^{22}$ investigated by DRIFT the reactivity of surface species and noted that carbonates were stable on the reduced ceria but were easily decomposed by reoxidation in either $\mathrm{O}_{2}$ or $\mathrm{H}_{2} \mathrm{O}$. These authors proposed that the carbonates probably acted as a poison and limited the rate at which the ceria could be reoxidized. In this respect, the suppression of the formation of surface carbonates was proposed as a means to obtain higher WGS reaction rates.

More recently, Flytzani-Stephanopoulos and co-workers ${ }^{32}$ published an interesting study that brought new insight into the effective role played by the metal in these ceria-supported catalysts. These authors removed most of the metal of ceriasupported gold and platinum catalysts (to the point of removing all the TEM observable particles) and showed that this treatment did not affect the activity of the catalyst compared to the untreated ones. Flytzani-Stephanopoulos and co-workers proposed that part of the metal, in the form of ions, diffused into the ceria and anchored to surface defects. These ions were proposed to be responsible for the increase in the reducibility of the support. The remaining part of the metal in the form of metallic nanoparticles was considered to be unimportant in the WGS reaction.

Flytzani-Stephanopoulos and co-workers advocated a mechanism similar to the "Normal-Support Activation" (NSA) effect summarized by Golunski et al., ${ }^{33}$ by which the addition of a metal to a reducible support leads to a modification of the reducibility of this support through the so-called "junction effect". This phenomenon was actually first proposed by Frost ${ }^{34}$ for methanol synthesis catalysts. This modification leads to a dramatic increase in the number of oxygen vacancies within the support, which become active sites. The most striking effect observed with the NSA is a reversal of the roles of the metal oxide and the precious metal through an encouragement of the formation of highly active sites on the phase that normally acts as the support.

Recent work by Goguet et al. ${ }^{35}$ on the deactivation of a Pt/ $\mathrm{CeO}_{2}$ catalyst provided more evidence regarding the involvement of the support in the reaction mechanism. It was proposed that during reaction a limited fraction of the support close to the metal particles could be in a highly reduced state and would correspond to the active part of the support.

We have recently shown that the reactivity of surface species can dramatically depend on the experimental procedure used during the RWGS reaction over $\mathrm{Pt} / \mathrm{CeO}_{2}{ }^{36}$ On the basis of DRIFT analysis combined with the utilization of isotopic tracers, these steady-state experiments showed that formates were less reactive than carbonyl and carbonate species under steady-state conditions, while the reverse trend was observed during the desorption-type non-steady-state experiments carried out in an inert purge gas.

The DRIFT + MS under SSITKA conditions used in the present study provides a powerful methodology for an in depth investigation of catalysts under reaction conditions. As a first stage to demonstrate this technique using a single reactor, the present paper deals with the reactivity of the surface species formed over a $2 \% \mathrm{Pt} / \mathrm{CeO}_{2}$ catalyst under RWGS conditions:

$$
\mathrm{CO}_{2}+\mathrm{H}_{2} \rightarrow \mathrm{CO}+\mathrm{H}_{2} \mathrm{O}
$$

However, it is recognized that different species could be important for the forward water gas shift reaction because the nature of the surface of the catalyst will depend on the composition of the reaction mixture. This will be the subject of future work.

\section{Experimental Section}

The catalyst used in this study was a $2 \% \mathrm{Pt} / \mathrm{CeO}_{2}$ provided by Johnson Matthey. The specific surface area, measured by the BET method on a Micromeretics ASAP 2010, was $180 \mathrm{~m}^{2}$ $\mathrm{g}^{-1}$. The Pt dispersion, measured by $\mathrm{H}_{2}$ chemisorption on a Micromeretics Autochem 2910 at $193 \mathrm{~K}$ to minimize potential spillover of $\mathrm{H}_{2}$ onto the support, ${ }^{37}$ was $17 \%$. The purity of the gases used (i.e., $\mathrm{H}_{2}, \mathrm{He}, \mathrm{CO}_{2}$, Ar, supplied by $\mathrm{BOC}$ ) was higher than $99.95 \%$. The ${ }^{13} \mathrm{CO}_{2}$ was $99 \%$ pure (supplied by Cambridge Isotope Laboratories Inc).

The experimental setup consisted of an in situ high-temperature diffuse reflectance IR cell (from Spectra-Tech) fitted with $\mathrm{ZnSe}$ windows. The reactor crucible was modified to ensure plug-flow conditions throughout the catalyst bed. The interface between the ceramic reactor and the metallic base plate was sealed with PTFE tape to prevent any sample by-pass. The original porous bed to support the sample was replaced by a metallic mesh. The catalytic conversion measured using the cell was equal to that measured in a conventional tubular plug-flow reactor. No conversion of reactant was observed when the crucible was heated to the reaction temperature in the absence of the catalyst. The cell was connected to the feed gas cylinders through low volume stainless steel lines. The gas flows were controlled by Aera mass flow controllers, which were regularly calibrated. A 4-way valve was used to allow a fast switching between two reaction feeds, when appropriate. The DRIFTS cell was located in a Bruker Equinox 55 spectrometer, operating at a resolution of $4 \mathrm{~cm}^{-1}$. The outlet of the DRIFT cell was connected to a quadrupole mass spectrometer (V. G. GASLAB 300). The mass spectrometer was equipped with a capillary inlet system with bypass allowing fast response (i.e., $100 \mathrm{~ms}$ ) for the sampling. Both feed lines were connected to an ultralow differential pressure transducer (Honeywell 395-257) and a high precision metering valve (Nupro) in order to control and tune the pressure of both feed lines.

The amount of $2 \% \mathrm{Pt} / \mathrm{CeO}_{2}$ catalyst used was always $80 \pm 5$ $\mathrm{mg}$ (particle diameter $<150 \mu \mathrm{m}$ ). Prior to any measurement, the sample was reduced in situ for $1 \mathrm{~h}$ at $573 \mathrm{~K}$ in a $50 \% \mathrm{H}_{2} /$ Ar mixture at a total flow of $40 \mathrm{~mL} \mathrm{~min}{ }^{-1}$. After the reduction step, the cell was purged with $\mathrm{He}$ and the temperature of the reactor was set to the desired value $(498 \mathrm{~K})$. The reaction mixture, i.e., $1 \%{ }^{12} \mathrm{CO}_{2}+4 \% \mathrm{H}_{2}$ in $\mathrm{Ar}$, was then introduced at 
a total flow rate of $100 \mathrm{~mL} \cdot \mathrm{min}^{-1}\left(\mathrm{GHSV}=\mathrm{ca} .21000 \mathrm{~h}^{-1}\right)$. Steady-state conditions, as far as the nature and concentration of surface species measured by DRIFTS are concerned, was reached in less than $30 \mathrm{~min}$. After at least $1 \mathrm{~h}$, the unlabeled gas feed was replaced with a $1 \%{ }^{13} \mathrm{CO}_{2}+4 \% \mathrm{H}_{2}$ mixture. Spectra were recorded at regular intervals (typically every $10 \mathrm{~s}$ ) for at least $30 \mathrm{~min}$ following the switch. A series of back and forth isotopic switches were carried out to assess the reproducibility and precision of the experiment.

The IR bands used for the quantification of the concentrations of the ${ }^{12} \mathrm{C}$-containing surface species of interest were as follows (the area of a given band was measured with the OPUS software, using a single-point baseline), all values being in $\mathrm{cm}^{-1}$ :

Formate: 2954-2944 (single-point baseline at 3000)

Carbonyl: 2070-2050 (single-point baseline at 2150)

Carbonate: $880-865$ (single-point baseline at 797)

These three wavenumber regions were selected as each of these was unequivocally related to one type of surface species (vide infra). The IR bands of these species exhibited a red-shift when the ${ }^{12} \mathrm{C}$ isotope was replaced with the heavier ${ }^{13} \mathrm{C}$ isotope. Since the shift in frequency was usually not sufficient to allow a complete resolution of the ${ }^{12} \mathrm{C}$ and ${ }^{13} \mathrm{C}-\mathrm{IR}$ bands, the integration of the intensity of the ${ }^{12} \mathrm{C}$-bands had therefore to be limited to the high-frequency part of the band where there was no contribution from the ${ }^{13} \mathrm{C}$-species.

In the case of the mass spectrometric analysis the recording of the masses $28,44,29,45$, and 4 (a.m.u) was started 10 min before the isotopic switches. Blank experiments without catalyst were also performed in order to determine the fragmentation coefficients of ${ }^{12} \mathrm{CO}_{2}$ with respect to the mass 28 and that of ${ }^{13} \mathrm{CO}_{2}$ with respect to the mass 29 . These coefficients were used to subtract the contribution of $\mathrm{CO}_{2}$ to mass 28 and 29 and extract the actual ${ }^{12} \mathrm{CO}(\mathrm{g})$ and ${ }^{13} \mathrm{CO}(\mathrm{g})$ concentration for each experiment. Note that the concentrations of the reactants and products were also determined using an on-line gas chromatograph (Perkin-Elmer 8700), equipped with a HayeSep Q column and a FID-fitted with a methanator to allow the detection of $\mathrm{CO}$ and $\mathrm{CO}_{2}$.

The microbalance experiments were carried out on a Setaram TG-DSC 111 thermobalance. The sample $(59.50 \mathrm{mg})$ was placed in an aluminum crucible and was exposed to the same reaction mixture as that used for the catalytic test at ambient pressure. Formic acid was introduced in the feed using a saturator placed in a thermostated bath at $273 \mathrm{~K}$. The reactant flows were regulated by Aera mass flow controllers.

For the sake of clarity, note that surface-bound carbon monoxide is referred to as carbonyl species or $\mathrm{CO}$ (ads), while the gas-phase carbon monoxide (main product of reaction along with water) is referred to as $\mathrm{CO}(\mathrm{g})$.

\section{Results}

Infrared Experiments. Several IR bands were readily observed following the introduction of the $1 \%{ }^{12} \mathrm{CO}_{2}+4 \% \mathrm{H}_{2}$ reaction mixture over the $2 \% \mathrm{Pt} / \mathrm{CeO}_{2}$ sample. Figure 1 shows a typical DRIFT spectrum obtained at $498 \mathrm{~K}$ after $1 \mathrm{~h}$ on stream.

The bands in the region $1600-1200 \mathrm{~cm}^{-1}$ were mostly due to the stretching vibration modes (symmetric and anti-symmetric) of the $\mathrm{O}-\mathrm{C}-\mathrm{O}$ group of free carboxylate, formate and carbonate species), as already described in detail in the literature..$^{15,38-42}$ Due to the complexity of this band structure, the deconvolution and interpretation of this region was not attempted. The bands in the $3650-3500 \mathrm{~cm}^{-1}$ region were due to the stretching vibration of the ceria surface hydroxyl groups, while that around $2360 \mathrm{~cm}^{-1}$ was associated with gas-phase

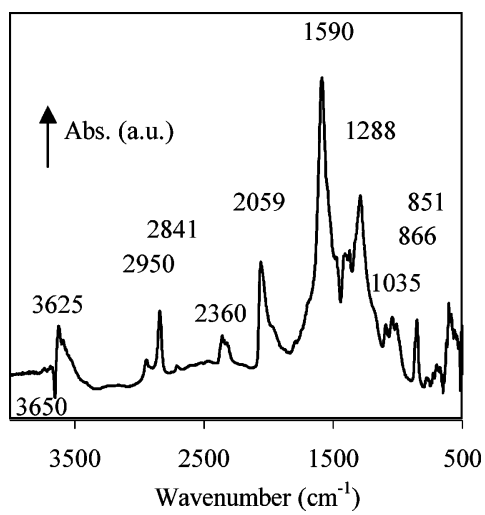

Figure 1. In situ DRIFTS spectrum of the species formed over the $2 \% \mathrm{Pt} / \mathrm{CeO}_{2}$ after $1 \mathrm{~h}$ on stream. $T=498 \mathrm{~K}$, feed: $1 \% \mathrm{CO}_{2}+4 \% \mathrm{H}_{2}$ in Ar.

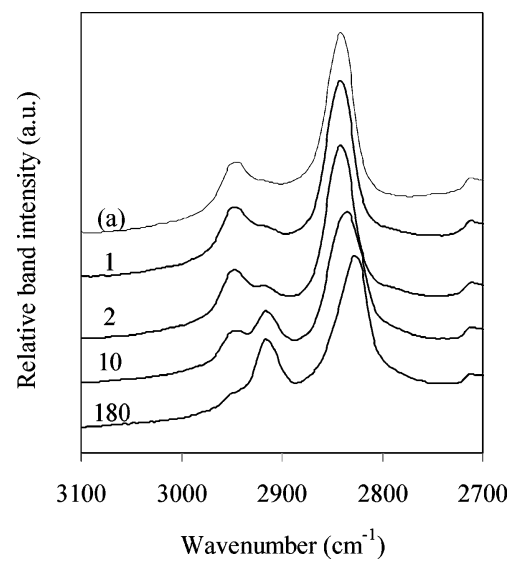

Figure 2. In situ DRIFTS spectra of the formate species formed over the $2 \% \mathrm{Pt} / \mathrm{CeO}_{2}$ after (a) $1 \mathrm{~h}$ under $1 \%{ }^{12} \mathrm{CO}_{2}+4 \% \mathrm{H}_{2}$ in $\mathrm{Ar}$ and subsequently exposed to the $1 \%{ }^{13} \mathrm{CO}_{2}+4 \% \mathrm{H}_{2}$ in $\mathrm{Ar}$ feed for 1,2 , 10 and 180 min. $T=498 \mathrm{~K}$.

(and possibly some weakly adsorbed) $\mathrm{CO}_{2}$. The triplet of bands around $1035 \mathrm{~cm}^{-1}$ was related to the $\mathrm{C}-\mathrm{O}$ stretching modes of the various species described above. The bands used for the quantitative analysis of the surface concentration of formates were the Fermi resonance doublet (i.e., combination of the stretching and bending vibration of the $\mathrm{C}-\mathrm{H}$ bond) at 2950 and $2841 \mathrm{~cm}^{-1}$ (see Experimental Section for integration details). The out-of-plane bending vibrations at 866 and $851 \mathrm{~cm}^{-1}$ were used to quantify the concentration of carbonate species, while the stretching vibration at $2059 \mathrm{~cm}^{-1}$ was used to measure the proportion of carbonyls. While the bands selected for the quantification of the concentration of surface species were unequivocally associated with one type of species, it is possible that different adsorption sites and/or adsorption mode (e.g., mono, bi, polydendate) could be considered in each case. In particular, the broad carbonyl band was most likely due to the presence of a distribution of heterogeneous adsorption sites, as can be expected over supported noble metal particles. ${ }^{41}$

The intensity of all the IR bands reached a steady-state value within the first hour on stream (typically in less than $30 \mathrm{~min}$ ) at the temperature investigated. Figure 2, 3 and 4 show the typical DRIFT spectra obtained at $498 \mathrm{~K}$ of the formate, carbonyl and carbonate species at steady-state in a feed containing $1 \%{ }^{12} \mathrm{CO}_{2}+4 \% \mathrm{H}_{2}$ at various times following the switch to the feed containing $1 \%{ }^{13} \mathrm{CO}_{2}+4 \% \mathrm{H}_{2}$.

The variation of the IR band intensity of the corresponding ${ }^{12} \mathrm{C}$-containing surface species as a function of time following the isotopic switch is plotted in Figure 5. For all species, the IR signal decreased in a somewhat (but not strictly) exponential 


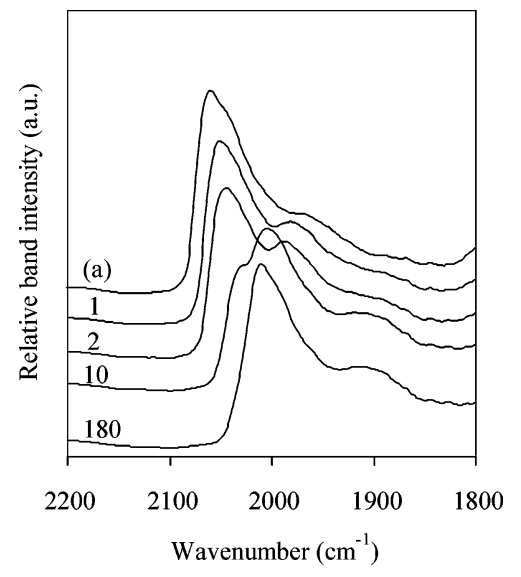

Figure 3. In situ DRIFTS spectra of the carbonyl species formed over the $2 \% \mathrm{Pt} / \mathrm{CeO}_{2}$ after (a) $1 \mathrm{~h}$ under $1 \%{ }^{12} \mathrm{CO}_{2}+4 \% \mathrm{H}_{2}$ in $\mathrm{Ar}$ and subsequently exposed to the $1 \%{ }^{13} \mathrm{CO}_{2}+4 \% \mathrm{H}_{2}$ in Ar feed for 1,2 , 10 and $180 \mathrm{~min} . T=498 \mathrm{~K}$

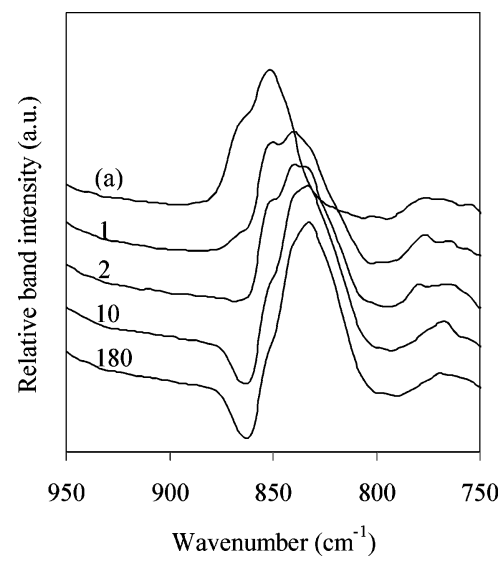

Figure 4. In situ DRIFTS spectra of the carbonate species formed over the $2 \% \mathrm{Pt} / \mathrm{CeO}_{2}$ after (a) $1 \mathrm{~h}$ under $1 \%{ }^{12} \mathrm{CO}_{2}+4 \% \mathrm{H}_{2}$ in $\mathrm{Ar}$ and subsequently exposed to the $1 \%{ }^{13} \mathrm{CO}_{2}+4 \% \mathrm{H}_{2}$ in $\mathrm{Ar}$ feed for 1,2 , 10 and $180 \mathrm{~min} . T=498 \mathrm{~K}$.

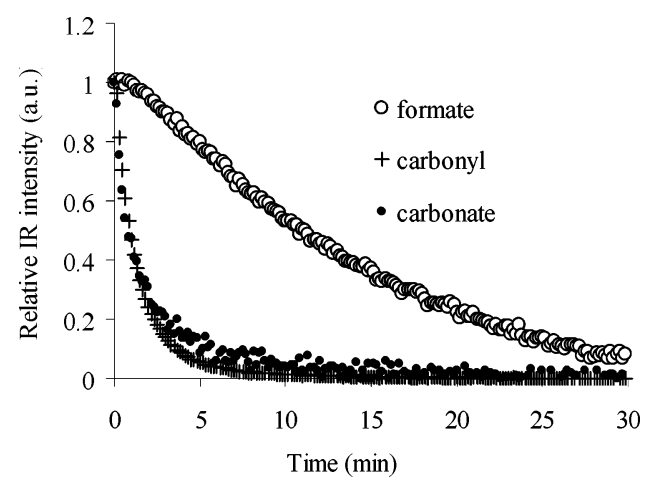

Figure 5. Normalized intensity of the IR bands of the ${ }^{12} \mathrm{C}$-containing (O) formate, $(+)$ carbonyl and $(\bullet)$ carbonate species over the $2 \% \mathrm{Pt} /$ $\mathrm{CeO}_{2}$ following the isotopic switch at $498 \mathrm{~K}$. Feed: $1 \%{ }^{13} \mathrm{CO}_{2}+4 \%$ $\mathrm{H}_{2}$ in Ar. The sample had initially been exposed to $1 \%{ }^{12} \mathrm{CO}_{2}+4 \%$ $\mathrm{H}_{2}$ in $\mathrm{Ar}$ for $1 \mathrm{~h}$.

manner. The value $\tau$, representing the time at which the signal of each species decreased by $50 \%$ following the isotopic switch, was measured as a means to quantify the rate of exchange. The $\tau$ values for the carbonate, carbonyl, and formate species were $48 \pm 5,54 \pm 5$ and $660 \pm 30 \mathrm{~s}$, respectively. The experiment was repeated several times (also in the opposite switching order) and identical values were obtained.

Gas Chromatography and Mass Spectrometry Measurements. The measurements performed with on-line analysis by

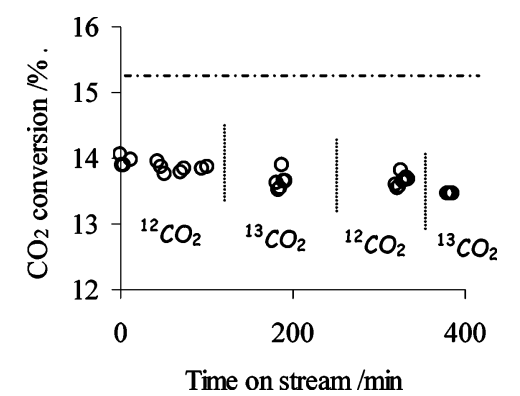

Figure 6. $\mathrm{CO}_{2}$ conversion measured over the $2 \% \mathrm{Pt} / \mathrm{CeO}_{2}$ at $498 \mathrm{~K}$ over a series of isotopic switches. Feed: $1 \%{ }^{13}$ or ${ }^{12} \mathrm{CO}_{2}+4 \% \mathrm{H}_{2}$ in Ar. The dotted line represents the conversion associated with the thermal equilibrium of the RWGS reaction in the specific conditions of reaction used.

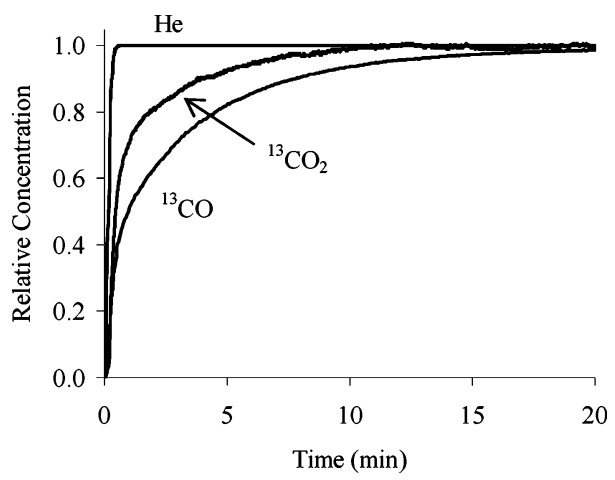

Figure 7. Relative concentrations measured by mass spectroscopy of the He tracer, the ${ }^{13} \mathrm{CO}_{2}(\mathrm{~g})$ reactant and the ${ }^{13} \mathrm{CO}(\mathrm{g})$ product during a typical isotopic switch from $1 \%{ }^{12} \mathrm{CO}_{2}(\mathrm{~g})+4 \% \mathrm{H}_{2} / \mathrm{Ar}$ to $1 \%{ }^{13} \mathrm{CO}_{2^{-}}$ (g) $+4 \% \mathrm{H}_{2}+2 \% \mathrm{He} / \mathrm{Ar}$ at $498 \mathrm{~K}$. The steady-state conversion of $\mathrm{CO}_{2}$ to $\mathrm{CO}$ was $13.7 \%$.

gas chromatography indicated that the conversion due to the empty reactor at the temperature of the experiment was negligible. In the presence of the $2 \% \mathrm{Pt} / \mathrm{CeO}_{2}$, the $\mathrm{CO}_{2}$ conversion measured before and after the isotopic switch were 13.7 $\pm 0.2 \%$ (Figure 6 ). This conversion was close to that associated with the thermodynamic equilibrium of the system (i.e., $15.2 \%$ at $498 \mathrm{~K}$ ). The selectivity to CO was always higher than $99 \%$ (only trace concentrations of methane were measured). Equilibrium conversions were attained above $523 \mathrm{~K}$ (data not shown), which indicates that any channeling or by-passing of the reactor was negligible. The conversion plot reported in Figure 6 also evidences that a slow deactivation was taking place, possibly due to carbon deposition ${ }^{35}$ on the catalyst or $\mathrm{Pt}$ sintering. ${ }^{26}$ Slow deactivation of the same catalyst under similar reaction conditions was reported elsewhere. ${ }^{35}$ These data show that, while being close to the thermodynamic equilibrium conversion, the rate of the RWGS was still significantly higher than that of the WGS in the present case.

Figure 7 shows typical normalized ${ }^{13} \mathrm{CO}_{2}(\mathrm{~g}),{ }^{13} \mathrm{CO}(\mathrm{g})$, and He MS traces obtained after an isotopic switch from a RWGS feed containing ${ }^{12} \mathrm{CO}_{2}$ to one containing ${ }^{13} \mathrm{CO}_{2}$ (and the $\mathrm{He}$ tracer) at $498 \mathrm{~K}$. The concentration of the tracer reached $50 \%$ of its steady-state value in less than $3 \mathrm{~s}$. As the total flowrate was $100 \mathrm{~cm}^{3} \mathrm{~min}^{-1}$, this indicated that the dead-volume of the system between the 4-way valve and the mass spectrometer was lower than $5 \mathrm{~cm}^{3}$ (a detailed description of the cell and its flow response will be reported elsewhere). The time response of the ${ }^{13} \mathrm{CO}_{2}$ species was significantly slower (i.e., about $18 \mathrm{~s}$ for $50 \%$ exchange), indicating a strong adsorption of this reactant. The characteristic time $\tau_{\mathrm{CO}(\mathrm{g})}$ at which the signal of the ${ }^{13} \mathrm{CO}(\mathrm{g})$ product reached $50 \%$ of its steady-state value was $54 \pm 6$ s. 


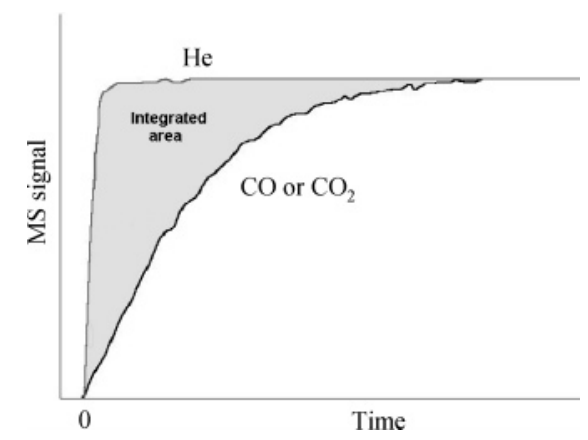

Figure 8. Scheme of the integration procedure used to quantify the active sites.

TABLE 1: Number of Moles of $\mathrm{CO}(\mathrm{g})$ and $\mathrm{CO}_{2}$ Released Per Gram of Catalyst Calculated from the MS Data, Ratio $\mathrm{CO}(\mathrm{g})$ Released/CO $/ \mathrm{O}_{2}$ Released and Ratio $\mathrm{CO}(\mathrm{g})$ Per Surface Platinum (calculated with a Pt dispersion of $17 \%$ )

\begin{tabular}{cccc}
\hline $\mathrm{CO}(\mathrm{g})\left(\mathrm{mol} / \mathrm{g}_{\text {cat }}\right)$ & $\mathrm{CO}_{2}\left(\mathrm{~mol} / \mathrm{g}_{\text {cat }}\right)$ & $\mathrm{CO}(\mathrm{g}) / \mathrm{CO}_{2}$ & $\mathrm{CO}(\mathrm{g}) / \mathrm{Pt}_{\text {surface }}$ \\
\hline $2.2 \times 10^{-4}$ & $8.4 \times 10^{-4}$ & 0.26 & 12
\end{tabular}

The quantity of surface intermediates precursors of $\mathrm{CO}(\mathrm{g})$ could be evaluated by integrating the area between the MS line of the tracer $(\mathrm{He})$ and that of $\mathrm{CO}(\mathrm{g})$ (Figure 8). ${ }^{43}$ Knowing the $\mathrm{CO}(\mathrm{g})$ concentration measured with the $\mathrm{GC}$, the integrated area yields directly the number of moles of, e.g., ${ }^{12} \mathrm{CO}(\mathrm{g})$ formed after switching to the ${ }^{13} \mathrm{CO}_{2}$-containing feed. This number of moles is equal to that of the ${ }^{12} \mathrm{C}$-containing $\mathrm{CO}(\mathrm{g})$ precursors present at the surface of the sample at the moment of the switch to the ${ }^{13} \mathrm{CO}_{2}$-containing feed. In a similar manner, the quantity of surface intermediates releasing $\mathrm{CO}_{2}$ could be calculated using the appropriate $\mathrm{CO}_{2} \mathrm{MS}$ signal.

Table 1 reports the number of moles of $\mathrm{CO}(\mathrm{g})$ and $\mathrm{CO}_{2}$ released per gram of catalyst calculated as indicated above, the ratio $\mathrm{CO}(\mathrm{g})$ released/ $\mathrm{CO}_{2}$ released and the ratio $\mathrm{CO}(\mathrm{g})$ per surface platinum (calculated with a Pt dispersion of 17\%).

These results yield two important pieces of information. First, the $\mathrm{CO}(\mathrm{g}) / \mathrm{CO}_{2}$ ratio indicates that about one molecule of $\mathrm{CO}(\mathrm{g})$ and four molecules of $\mathrm{CO}_{2}$ were released out of five $\mathrm{CO}_{x}$ surface precursors. (note: this is not an indication that different surface precursors are involved in each case, e.g., a given surface intermediate could react/decompose in various ways). Second, the $\mathrm{CO}(\mathrm{g}) / \mathrm{Pt}_{\text {surface }}$ ratio indicates that the number of $\mathrm{CO}$ precursors is more than 10 times higher than the number of surface platinum atoms.

A couple of experiments using a flow microbalance was used to estimate the typical surface concentration of formates that was formed over the catalyst at $498 \mathrm{~K}$. First, the mass loss (data not shown) measured after $1 \mathrm{~h}$ desorption in Ar at $498 \mathrm{~K}$ of the surface species formed under our typical RWGS conditions was ascribed to the decomposition of formates to $\mathrm{CO}(\mathrm{g})$. This value, which overestimates the concentration of formates since some carbonyls and some carbonates are also lost in the process, ${ }^{36}$ was found to be $1.4 \times 10^{-4} \mathrm{~mol} / \mathrm{g}_{\text {cata. }}$. In another experiment (not shown), the prereduced catalyst was contacted with formic acid vapors at $498 \mathrm{~K}$ and the uptake of acid at saturation corresponded to $3.3 \times 10^{-4} \mathrm{~mol} / \mathrm{g}_{\text {cata. }}$. Both these overestimations of the surface concentration of formates during RWGS conditions at $498 \mathrm{~K}$ are similar to that of $\mathrm{CO}(\mathrm{g})$ precursors calculated by the MS data (Table 1), i.e. $2.2 \times 10^{-4} \mathrm{~mol} / \mathrm{g}_{\text {cata }}$.

\section{Discussion}

The simultaneous combination of mass spectrometry and DRIFT spectroscopy during SSITKA-type experiments has yielded crucial information about the operando rate of exchange of gas-phase reaction products and that of reaction intermediates present on the surface of a $2 \% \mathrm{Pt} / \mathrm{CeO}_{2}$ during the RWGS at $498 \mathrm{~K}$. On one hand, the mass spectrometry results showed that the characteristic exchange time $\tau_{\mathrm{CO}(\mathrm{g})}$ (defined here as the time needed to achieve $50 \%$ exchange) between the two isotopes (i.e., ${ }^{12} \mathrm{CO}(\mathrm{g})$ and $\left.{ }^{13} \mathrm{CO}(\mathrm{g})\right)$ of the main reaction product was $54 \pm 6 \mathrm{~s}$. It is important to note that $\tau_{\mathrm{CO}(\mathrm{g})}$ relates to the ratedetermining-step of the reaction.

On the other hand, the simultaneous DRIFT measurements revealed that the characteristic time of isotopic exchange (defined as the time needed to remove $50 \%$ of the ${ }^{12} \mathrm{C}$-containing species) of the carbonyl, carbonate, and formate surface species were $48 \pm 5,54 \pm 5$, and $660 \pm 30 \mathrm{~s}$, respectively.

The rate of isotopic exchange of a main surface intermediate must be equal to (or faster than) the rate of isotopic exchange of the corresponding reaction product. Therefore, it is clear that the formate species observed by DRIFTS is not a main reaction intermediate in the formation of $\mathrm{CO}(\mathrm{g})$, since the corresponding exchange time (i.e., ca. $600 \mathrm{~s}$ ) was significantly longer than $\tau_{\mathrm{CO}(\mathrm{g})}=54 \pm 6 \mathrm{~s}$. However, it should be stressed that formates have been shown to yield $\mathrm{CO}(\mathrm{g})^{\mathbf{1 5}}$ and a significant fraction of these species probably do in the present case, although at a slower rate than at least one other surface intermediate. Hence, the formates (at least those that were observed by DRIFTS) are better referred to as minor reaction intermediates, rather than truly "spectator" species.

It is yet possible that a minor fraction of very reactive formates species did exist and that the DRIFTS signal of those could have been masked by that of the less reactive formates. However, the microbalance data indicated that the surface concentration of formates (i.e., overestimated at around $1.4 \times$ $10^{-4} \mathrm{~mol} / \mathrm{g}_{\text {cata }}$ and $\left.3.3 \times 10^{-4} \mathrm{~mol} / \mathrm{g}_{\text {cata }}\right)$ was just of the same order of magnitude as that of the $\mathrm{CO}(\mathrm{g})$ precursors (i.e., $2.2 \times$ $10^{-4} \mathrm{~mol} / \mathrm{g}_{\text {cata }}$,). If a very reactive formate species not evidenced by the DRIFTS data existed, it would represent only a minor fraction of the overall formates and, therefore, the surface concentration of those would largely be insufficient to account for all the $\mathrm{CO}(\mathrm{g})$ formed. Hence, these hypothetical "very reactive" formates would also be considered as minor reaction intermediates.

In the case of the carbonyl species, the half-life time is similar to $\tau_{\mathrm{CO}(\mathrm{g})}$ and therefore carbonyl species are potentially important reaction intermediates in the formation of $\mathrm{CO}(\mathrm{g})$. However, the $\mathrm{CO}(\mathrm{g}) / \mathrm{Pt}_{\text {surface }}$ ratio derived from the MS data (Figure 8 and Table 1) shows that the number of surface intermediate precursors of $\mathrm{CO}(\mathrm{g})$ is more than 10 times larger than the available number of surface platinum atoms, while each surface platinum atom can typically accommodate only 1.25 carbonyl groups at the most. ${ }^{44}$ Therefore, a reaction pathway involving only the dissociative adsorption of $\mathrm{CO}_{2}$ on $\mathrm{Pt}$ followed by carbonyl desorption from the metal to give $\mathrm{CO}(\mathrm{g})$ can be discarded. There must be another carbon-containing surface intermediate to account for the quantity of $\mathrm{CO}(\mathrm{g})$ observed during the isotopic switch.

A reaction scheme involving $\mathrm{CO}_{2}$ adsorption on the support followed by reaction to form carbonate species followed by the reduction of those to $\mathrm{CO}(\mathrm{g})$ is in agreement with all the experimental results reported here. First, the exchange time of the carbonates (i.e., $54 \pm 5 \mathrm{~s}$ ) is similar to $\tau_{\mathrm{CO}(\mathrm{g})}$ (i.e., $54 \pm 6$ s). Second, the number of (basic) adsorption sites available for the formation of carbonates from $\mathrm{CO}_{2}(\mathrm{~g})$ on this high surface area ceria support is far greater than the number of surface $\mathrm{Pt}$ atoms and is sufficient to account for all the $\mathrm{CO}(\mathrm{g})$ and $\mathrm{CO}_{2}$ 


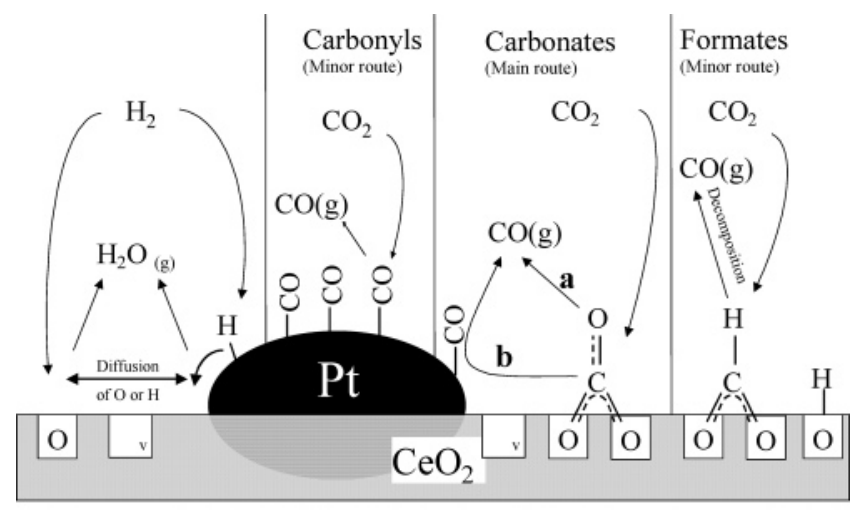

$\mathrm{v}=$ oxygen vacancy

Figure 9. Model for the reaction mechanism of the RWGS reaction over $\mathrm{Pt} / \mathrm{CeO}_{2}$.

precursors found on the sample surface. $\left(\mathrm{CeO}_{2}\right.$ has a cubic cell with 4 oxygen atoms on each face, the surface area of which is ca. $2.92 \times 10^{-19} \mathrm{~m}^{2}$. The theoretical number of moles of oxygen atoms, or oxide ions, per $\mathrm{m}^{2}$ of catalyst surface is $22.7 \times 10^{-6}$. In the present work, about $5.89 \times 10^{-6}$ moles of $\mathrm{CO}_{x}$ per $\mathrm{m}^{2}$ of catalyst surface were adsorbed).

It should be stressed that several reaction pathways could be envisaged for the carbonates (see Figure 9). It is possible that the carbonates would directly react with oxygen vacancies in the ceria, from which $\mathrm{CO}(\mathrm{g})$ would be directly released (pathway noted "a" in Figure 9). The main role of the Pt in this case would be to remotely generate oxygen vacancies (by activating $\mathrm{H}_{2}$, for instance), which would then migrate over the ceria. In this case, the rate-determining-step (RDS) of the RWGS could be the reaction between the surface carbonate and the oxygen vacancy or the diffusion of the vacancy. Another reaction pathway (noted "b" in Figure 9) could involve the surface migration of a carbonate toward the platinum-ceria interface, at which it would decompose via Pt-bound carbonyl intermediates. In such a case, the desorption of the corresponding Ptbound $\mathrm{CO}$ (ads) could be the RDS.

The route (a) could be supported by results from Gorte and co-workers which showed that $\mathrm{CO}_{2}$ can directly re-oxidize ceria. ${ }^{45}$ A comparative study between a fresh $\mathrm{Pd} /$ Ceria catalyst and the same sample poisoned with $\mathrm{SO}_{2}$ has shown that $\mathrm{CO}_{2}$ can only reoxidize the nonsulfated material. ${ }^{46}$ Since the poisoning left the metal unaffected and only affected the ceria, these results provide further evidence for the mechanism in which the $\mathrm{CO}_{2}$ adsorbs and reacts mostly with the ceria, rather than on the noble metal. However, there is no clear experimental evidence at the present time to favor either of the two reaction pathways (a) and (b) (see Figure 9) for the carbonates.

In the model supporting the reaction over the ceria, it is conceivable that the active sites would be located in the vicinity of the Pt particles, as noble metals profoundly modify the redox properties of the ceria. ${ }^{35,47}$ In this latter case, it is possible to derive additional information from the quantification of the number of active sites (see Table 1). If we consider that the carbonate species are homogeneously distributed on the catalyst surface, then the portion of surface $\left(A_{\mathrm{CO}}\right)$ where the active sites are located can be calculated knowing the fraction of these species that react to give $\mathrm{CO}(\mathrm{g})$ with respect to those that readsorb as $\mathrm{CO}_{2}$ (Table 1):

$$
A_{\mathrm{CO}}=\frac{A_{\mathrm{Sp}} \times N_{\mathrm{CO}}}{N_{\mathrm{CO}_{2}}}=47.7 \mathrm{~m}^{2} \times g_{\text {cat }}{ }^{-1}
$$

where, $A_{\mathrm{sp}}$ is the specific surface area of the catalyst and is equal to $180 \mathrm{~m}^{2} \mathrm{~g}^{-1} ; N_{\mathrm{CO}}$ the number of active sites calculated from the ${ }^{13} \mathrm{CO}(\mathrm{g})$ that is $0.222 \times 10^{-3} \mathrm{~mol} \mathrm{~g}_{\text {cat }}{ }^{-1}$ (Table 1 ); $N_{\mathrm{CO}_{2}}$ the number of adsorption sites for $\mathrm{CO}_{2}$ calculated from the ${ }^{13} \mathrm{CO}_{2}$ signal and is equal to $0.839 \times 10^{-3} \mathrm{~mol} \mathrm{~g}_{\text {cat }}{ }^{-1}$ (Table 1).

While it is not yet clear whether the RWGS depends on the Pt particle size ${ }^{32}$ the average radius of the platinum particles on the sample used here was calculated from the platinum dispersion (i.e., 17\%), and found to be ca. $3.5 \mathrm{~nm}$. The Pt species (e.g., $\mathrm{Pt}^{n+}$ ) responsible for the formation of active sites on the support via the "Normal-Support Activation" effect would be most likely located at the interface between the Pt particles and the ceria. Therefore, the active sites could be distributed in a disk on the support around the platinum particles. According to this model, it is possible to calculate the dimension of the "ring of active area" surrounding each metal particle $\left(R_{1}\right.$ for the Pt particle radius $(3.5 \mathrm{~nm}), R_{2}$ for the radius of the "active area": the Pt particles were considered to be hemispherical). The calculation gave a value of $R_{2}$ equal to $46 \mathrm{~nm}$. Note that if we assume that the Pt particles are equally spaced on the surface of the support, the distance between two particles would be ca. $150 \mathrm{~nm}$.

It is interesting to note that the radius of this "active area" is comparable to the magnitude of the radius that was calculated with the results obtained from the study of the deactivation of this same material. ${ }^{35}$ The data reported in this previous work showed that carbon deposition was responsible for the deactivation of the catalyst and took place in the vicinity of the platinum particles. In a case where the catalyst deactivated by $80 \%$ of its initial activity, it was found that the "ring" of carbon deposit surrounding each metal particles had a radius equal to $13 \mathrm{~nm}$. The fact that the zone of deactivation (i.e., $13 \mathrm{~nm}$ ) is somewhat smaller than the "active zone" (i.e., $46 \mathrm{~nm}$ ) in the present work could indicate that diffusion across the deactivated surface is restricted and so the catalyst loses its activity even though some of the "active zone" would still be available for reaction.

While our data have clearly shown that the RWGS over the present catalyst and conditions proceeds via surface carbonate intermediates, possibly followed by Pt-bound carbonyls, the pathway for activation of the hydrogen is not yet clear. Hydrogen is oxidized to water and several hypotheses can be formulated. The first would involve the adsorption of hydrogen on $\mathrm{Pt}$ sites (free of $\mathrm{CO}$ ) and migration of oxygen from the support to the Pt-ceria interface for reaction. This possibility would be supported by results showing that Pd particles were completely oxidized by a ceria-zirconia film on mild heating in a vacuum. ${ }^{48}$ This route could also involve a transfer of the hydrogen from the metal to the support.

A second hypothesis is the reaction of the hydrogen and the oxygen directly on the support. In this situation, the platinum would not be involved directly in the reaction pathway. The platinum could act as a modifier of the support properties and all the reaction would take place on the support, as in the "Junction effect" proposed by Frost ${ }^{34}$ or the "Normal-Support Activation" effect summarized by Golunski et al. ${ }^{33}$ This hypothesis seems to be supported by work on $\mathrm{CO}$ oxidation with ceria-based catalysts. Indeed, Hardacre et al. ${ }^{49}$ proposed that, in the case of $\mathrm{CO}$ oxidation, the ceria in the vicinity of the noble metal could become active. Recent work on the WGS with gold catalysts seems to provide further evidence for this hypothesis. ${ }^{32}$ The results obtained in the present study do not allow discrimination between these various hypotheses for the oxidation of hydrogen to water.

It is interesting to note that a parallel can be made between these results and mechanistic investigations of $\mathrm{CO}_{2}$ hydrogena- 
tion and $\mathrm{CO}_{2}$ reforming of methane over catalysts based on reducible supports. In this regard, Koeppel et al. ${ }^{50}$ investigated $\mathrm{Au} / \mathrm{ZrO}_{2}$ catalysts for $\mathrm{CO}_{2}$ hydrogenation using DRIFT and observed the formation of various formates and carbonates. These authors proposed that $\mathrm{CO}(\mathrm{g})$ formation from $\mathrm{CO}_{2}$ proceeded via surface carbonate in a surface reaction analogous to the RWGS model proposed here. Lercher and co-workers ${ }^{51}$ and Ross and co-workers ${ }^{52}$ also used DRIFT to investigate $\mathrm{CO}_{2}$ reforming of methane over $\mathrm{ZrO}_{2}$-based catalysts and discussed the formation and roles of surface formates and carbonates in the reaction. In this latter case, it was proposed that the formates could be involved in the reaction mechanism. The reduction of $\mathrm{CO}_{2}$ was proposed to occur via initial formation of carbonates close to the metal-support boundary, which were further reduced to formates and $\mathrm{CO}(\mathrm{g})$ by carbon formed from methane decomposition on the metal. These studies are clear evidence of the potential roles of formates and carbonates as surface intermediates on reducible supports such as ceria and zirconia. As the surface intermediates involved in these reactions are similar to those observed in the present study, there would be much interest in studying dry-reforming and $\mathrm{CO}_{2}$-hydrogenation reactions using the improved DRIFT + MS/SSITKA technique presented here.

\section{Conclusions}

The combination of mass spectrometry and DRIFT analysis during SSITKA-type experiments using a single reactor is a valuable tool that can be used to unravel the role of the different surface species present on catalyst surfaces in operando. The comparison of the isotopic exchange rate of the surface species, measured by DRIFT analysis, with the rate of exchange of gasphase species measured by mass spectrometry allows discrimination between active and spectator species. Additional quantitative information about the number of active sites can also be obtained.

In the case of the RWGS reaction over a $\mathrm{Pt} / \mathrm{CeO}_{2}$ catalyst, the results obtained can be used to discard the formate species observed by DRIFTS as a main reaction intermediate, although the formation of $\mathrm{CO}(\mathrm{g})$ from formates is likely to occur to a limited extent. Further analysis by quantification of the number of active sites showed that the Pt-carbonyl species cannot be the only reaction intermediates. Our data have clearly shown for the present catalyst and conditions that the RWGS reaction proceeds via surface carbonate intermediates, possibly followed by the formation of Pt-bound carbonyls. A reaction scheme involving a direct reoxidation of the support by the $\mathrm{CO}_{2}$ was proposed.

In a more general respect, the simultaneous DRIFT + MS/ SSITKA technique provides unique information about the nature of surface species (as spectator or reaction intermediate) for any reaction on catalysts under steady-state reaction conditions, providing only that the surface species are observable by DRIFT spectroscopy and one or more of the reactants can be isotopically labeled.

Acknowledgment. The authors gratefully acknowledge the financial support of Johnson Matthey Plc. The referees are also acknowledged for their very useful suggestions, in particular with respect the use of plain ceria for future experiments and the comments regarding the role of formates.

\section{References and Notes}

(1) Weckhuysen, B. M. Phys. Chem. Chem. Phys. 2003, 5, 4351 5979.

2) Peil, K. P.; Goodwin, J. G.; Marcelin, G. J. Phys. Chem. 1989, 93
(3) Nwalor, J. U.; Goodwin, J. G.; Biloen, P. J. Catal. 1989, 117, 121.

(4) Stockwell, D. M.; Chung, J. S.; Bennett, C. O. J. Catal. 1988, 112, 135.

(5) Efstathiou, A. M.; Chafik, T.; Bianchi, D.; Bennett, C. O. J. Catal. 1994, 147, 24.

(6) Efstathiou, A. M.; Chafik, T.; Bianchi, D.; Bennett, C. O. J. Catal. $1994,148,224$

(7) Agnelli, M.; Swaan, H. M.; Marquez-Alvarez, D.; Martin, G. A.; Mirodatos, C. J. Catal. 1998, 175, 117.

(8) Balakos, M. W.; Chuang, S. S. C.; Srinivas, G. J. Catal. 1993, 140, 281.

(9) Schuurman, Y.; Mirodatos, C. Appl. Catal. A 1997, 151, 305.

(10) Kroll, V. C. H.; Swaan, H. M.; Lacombe, S.; Mirodatos, C. J. Catal. 1997, 164, 387.

(11) Chafik, T.; Efstathiou, A. M.; Verykios, X. E. J. Phys. Chem. B 1997, 101, 7968.

(12) Costa, C. N.; Efstathiou, A. M. J. Phys. Chem. B 2004, 108, 2620.

(13) Whittington, B. I.; Jiang, C. J.; Trimm, D. L. Catal. Today 1995 $26,41$.

(14) Barbier Jr., J.; Duprez, D. Appl. Catal. B 1994, 4, 105.

(15) Shido, T.; Iwasawa, Y. J. Catal. 1993, 141, 71.

(16) Kummer, J. T. J. Phys. Chem. 1986, 90, 4747.

(17) Su, E. C.; Rothschild, W. G. J. Catal. 1986, 99, 506.

(18) Hertz, R. K.; Sell, J. A. J. Catal. 1985, 94, 166.

(19) Taylor, K. C. Automobile Catalytic Converters. In. Catalysis: Science and Technology; Anderson, J. R., Boudard, M., Eds.; Springer: Berlin, 1984, Vol. 5.

(20) Bunluesin, T.; Gorte, R. J.; Graham, G. W. Appl. Catal. B 1998, $15,107$.

(21) Zalc, J. M.; Sokolvskii, V.; Löffler, D. G. J. Catal. 2002, 206, 169.

(22) Hilaire, S.; Wang, X.; Luo, T.; Gorte, R. J.; Wagner, J. Appl. Catal. A 2001, 215, 271.

(23) Wang, X.; Gorte, R. J. Catal. Lett. 2001, 73, 15.

(24) Fu, Q.; Weber, A.; Flytzani-Stephanopoulos, M. Catal. Lett. 2001, $77,87$.

(25) Luo, T.; Gorte, R. J. Catal. Lett. 2003, 85, 139.

(26) Wang, X.; Gorte, R. J.; Wagner, J. P. J. Catal. 2002, 212, 225.

(27) Bunluesin, T.; Gorte, R. J.; Graham, G. W. Appl. Catal. B 1997, $14,105$.

(28) Cordatos, H.; Bunluesin, T.; Stubenrauch, J. S.; Vohs, J. M.; Gorte,

R. J. J. Phys. Chem. 1996, 100, 785.

(29) Li, Y.; Fu, Q.; Flytzani-Stephanopoulos, M. Appl. Catal. B 2000, 27,179

(30) Jacobs, G.; Williams, L.; Graham, U.; Sparks, D.; Davis, B. H. J. Phys. Chem. B 2003, 107, 10398.

(31) Jacobs, G.; Chenu, E.; Patterson, P. M.; Williams, L.; Sparks, D.; Thomas, G.; Davis, B. H. Applied. Catal. A. 2004, 258, 203.

(32) Fu, Q.; Saltsburg, H.; Flytzani-Stephanopoulos, M. Science 2003, 301,935 .

(33) Golunski, S.; Rajaram, R.; Hodge, N.; Hutchings, G. J.; Kiely, C. J. Catal. Today 2002, 72, 107.

(34) Frost, J. C. Nature 1988, 334, 577.

(35) Goguet, A.; Meunier, F. C.; Breen, J. P.; Burch, R.; Petch, M. I.; Faur Ghenciu, A. J. Catal. 2004, 226, 382.

(36) Tibiletti, D.; Goguet, A.; Meunier, F. C.; Breen, J. P.; Burch, R Chem. Commun, 2004, 1636.

(37) Bernal, S.; Botana, F. J.; Calvino, J. J.; Cauqui, M. A.; Jobacho, G. A.; Pintado, J. M.; Rodriguez-Izquierdo, J. M. J. Phys. Chem. 1993, 97, 4118.

(38) Li, C.; Sakata, Y.; Arai, T.; Domen, K.; Maruya, K.; Onishi, T. J. Chem. Soc., Faraday Trans. 1989, 85, 1451.

(39) Li, C.; Sakata, Y.; Arai, T.; Domen, K.; Maruya, K.; Onishi, T. J. Chem. Soc., Faraday Trans. 1989, 85, 929.

(40) Binet, C.; Daturi, M.; Lavalley, J. C. Catal. Today 1999, 50, 207.

(41) Bourane, A.; Dulaurent, O.; Bianchi, D. J. Catal. 2000, 196, 115

(42) Tabakova, T.; Boccuzzi, F. B.; Manzoli, M.; Andreeva, D. Appl. Catal., A, 2003, 252, 385.

(43) Burch, R.; Shestov, A. A.; Sullivan, J. A. J. Catal. 1999, 182, 497.

(44) Wells, P. B. Appl. Catal. 1985, 18, 259

(45) Sharma, S.; Hilaire, S.; Vohs, J. M.; Gorte, R. J.; Jen, H.-W. J. Catal. 2000, 190, 199.

(46) Luo, T.; Gorte, R. J. Catal. Lett. 2003, 85, 139.

(47) Kaspar, J.; Fornasiero, P.; Graziani, M. Catal. Today 1999, 50, 285

(48) Smirnov, M. Y., Graham, G. W. Catal. Lett. 2001, 72, 39

(49) Hardacre, C.; Ormerod, R. M.; Lambert, R. M. J. Phys. Chem. 1994, 98, 10901

(50) Koeppel, R. A.; Baiker, A.; Schild, C.; Wokaun, A. J. Chem. Soc., Faraday Trans. 1991, 87, 2821.

(51) Bitter, J. H.; Seshan, K. Lercher, J. A. J. Catal. 1998, 176, 93.

(52) O'Connor, A. M.; Meunier, F. C.; Ross, J. R. H. Stud. Surf. Sci. Catal. 1998, 119, 819 . 